\title{
Description of SGOT and SGPT Levels in Pregnant Women with Confirmed COVID-19
}

\author{
Gambaran Nilai SGOT dan SGPT pada Wanita Hamil Terkonfirmasi COVID-19
}

\author{
Clara V. I. Ponto, ${ }^{1}$ Glady I. Rambert, ${ }^{2}$ Mayer F. Wowor ${ }^{2}$
}

\author{
${ }^{1}$ Program Studi Pendidikan Dokter Fakultas Kedokteran Universitas Sam Ratulangi Manado, \\ Indonesia \\ ${ }^{2}$ Bagian Patologi Klinik Fakultas Kedokteran Universitas Sam Ratulangi, Manado, Indonesia \\ Email: claraviponto@gmail.com \\ Received: January 13, 2022; Accepted: February 4, 2022; Published on line: February 13, 2022
}

\begin{abstract}
Physiological changes that occur during pregnancy cause pregnant women to become more susceptible to be infected with SARS-CoV-2 that could cause liver disorders. This study aimed to determine the overview of serum glutamic oxaloacetic transaminase (SGOT) and serum glutamic-pyruvic transaminase (SGPT) levels in pregnant women with COVID-19 This was a descriptive study with a retrospective approach using secondary data in the form of patient medical records at Prof. Dr. R. D. Kandou Hospital in the period of July-August 2021. The results showed that based on the SGOT level among the second trimester patients, 1 patient $(50 \%)$ had an increased SGOT in the range of 27-54 U/L and 1 patient (50\%) had normal SGOT levels $(<27$ $\mathrm{U} / \mathrm{L})$. Among the third trimester patients, 15 patients $(31 \%)$ had increased SGOT in the range of 26-53 U/L, 9 patients (18\%) with increased SGOT $>52 \mathrm{U} / \mathrm{L}$, and 25 patients $(51 \%)$ had normal SGOT. Based on SGPT levels among the second trimester patients, both patients $(100 \%)$ had normal SGPT $(<35 \mathrm{U} / \mathrm{L})$, while in the third trimester patients, 4 patients $(8 \%)$ had increased SGPT in the range of 29-58 U/L, 4 patients (8\%) had increased SGPT >58 U/L, and 41 patients (84\%) had normal SGPT $(<29 \mathrm{U} / \mathrm{L})$. In conclusion, most of the patients had normal SGOT and SGPT levels. There were more patients with increased SGOT than those with increased SGPT.
\end{abstract}

Keywords: COVID-19; pregnant women; SGOT; SGPT

\begin{abstract}
Abstrak: Perubahan fisiologis yang terjadi selama kehamilan menyebabkan wanita hamil lebih mudah terinfeksi SARS-CoV-2 dan mengalami gangguan pada hati. Penelitian ini bertujuan untuk mengetahui gambaran serum glutamic oxaloacetic transaminase (SGOT) and serum glutamicpyruvic transaminase (SGPT) pada wanita hamil terkonfirmasi COVID-19. Jenis penelitian ialah deskriptif dengan pendekatan retrospektif menggunakan data sekunder berupa rekam medik pasien di RSUP Prof. Dr. R. D. Kandou periode Juli-Agustus 2021. Hasil penelitian memperlihatkan distribusi nilai SGOT pada pasien trimester II, didapatkan 1 pasien (50\%) mengalami peningkatan SGOT pada rentang 27-54 U/L dan 1 pasien (50\%) memiliki nilai SGOT normal, yaitu <27 U/L. Pada pasien trimester III, terdapat 15 pasien $(31 \%)$ yang mengalami peningkatan SGOT pada rentang 26-52 U/L, 9 pasien (18\%) dengan peningkatan nilai SGOT $>52$ U/L, dan 25 pasien (51\%) memiliki nilai SGOT normal, yaitu <26 U/L. Pada distribusi nilai SGPT pasien trimester II, kedua pasien (100\%) memiliki nilai SGPT normal, yaitu <35 U/L, sedangkan pada pasien trimester III, terdapat 4 pasien (8\%) yang mengalami peningkatan SGPT pada rentang $29-58 \mathrm{U} / \mathrm{L}, 4$ pasien (8\%) mengalami peningkatan SGPT >58 U/L, dan 41 pasien (84\%) memiliki nilai SGPT normal, yaitu <29 U/L. Simpulan penelitian ini ialah sebagian besar pasien memiliki SGOT dan SGPT normal. Pasien yang mengalami peningkatan SGOT lebih banyak daripada pasien yang mengalami peningkatan SGPT.
\end{abstract}

Kata kunci: COVID-19; wanita hamil; SGOT; SGPT 


\section{PENDAHULUAN}

Coronavirus disease 2019 (COVID-19) merupakan penyakit yang disebabkan oleh severe acute respiratory syndrome coronavirus 2 (SARS-CoV-2). COVID-19 muncul pertama kali di Wuhan, Cina pada bulan Desember tahun 2019. ${ }^{1}$ Bulan Maret 2020, Organisasi Kesehatan Dunia atau World Health Organization (WHO) mendeklarasikan COVID-19 sebagai pandemi, ${ }^{2}$ dan tanggal 3 Oktober 2021, SARS-CoV-2 telah menginfeksi lebih dari 234 juta jiwa di dunia dan lebih dari 4 juta jiwa di Indonesia. Dari jumlah kasus tersebut, tercatat 4.796.171 kematian di dunia dan 142.173 kematian di Indonesia. ${ }^{3}$ Di Sulawesi Utara, 34.229 jiwa terdeteksi positif COVID-19 dan 1.030 jiwa meninggal dunia. ${ }^{3}$

Menurut National Health Commission of China, dari 50 Rumah Sakit di Wuhan, sejak tanggal 8 Desember 2019 hingga 20 Maret 2020, terdapat 118 wanita hamil terkonfirmasi COVID-19, 92\% merupakan kasus ringan dan $8 \%$ kasus sedang dengan satu orang harus menggunakan ventilator. ${ }^{4}$ Risiko abortus akan semakin besar karena kondisi ibu menurun sehingga mengganggu aliran nutrisi dan oksigen dari ibu kepada janin melalui plasenta. ${ }^{5}$ Wanita hamil dengan COVID-19 mengalami gejala lebih berat pada gelombang kedua daripada gelombang pertama COVID-19. Intensive Care National Audit \& Research Centre melaporkan peningkatan kasus wanita hamil (16-49 tahun) dengan COVID-19 yang memerlukan perawatan intensif dari gelombang pertama ke gelombang kedua, yaitu 70 orang (1 Maret - 31 Agustus 2020) menjadi 277 orang (1 September 2020 - 4 Maret 2021). ${ }^{6}$ Di Spanyol, wanita hamil dengan COVID-19 yang masuk Rumah Sakit pada gelombang kedua meningkat sepuluh kali daripada gelombang pertama. ${ }^{7}$ Perkumpulan Obstetri dan Ginekologi Indonesia (POGI) mengemukakan sejak April 2020 sampai April 2021 terdapat $536 \mathrm{ibu}$ hamil positif COVID-19 dengan 51,9\% tanpa gejala, $4,5 \%$ masuk ICU, dan $3 \%$ meninggal. ${ }^{8}$ Transmisi COVID-19 secara vertikal (dari ibu ke janin), mungkin dapat terjadi, namun diperlukan bukti yang memadai. Suatu studi di 50 Rumah Sakit di Wuhan, Cina menunjukkan, dari 55 kasus kehamilan dengan COVID-19, 46 neonatus yang lahir tidak menunjukkan adanya transmisi COVID-19 secara vertikal. ${ }^{9}$

Gejala COVID-19 umumnya berupa demam, batuk kering, myalgia, fatigue, dispnea, beberapa pasien juga mengalami nyeri abdomen, diare, mual dan muntah. ${ }^{10}$ Gejala digestif berhubungan dengan adanya reseptor angiotensin-converting-enzyme 2 (ACE2) pada enterosit, hepatosit, dan kolangiosit, ${ }^{11}$ sehingga SARS-CoV-2 dapat menginfeksi dan menyebabkan gangguan pada hati dan saluran empedu. Tes fungsi hati yang abnormal terjadi pada banyak kasus COVID-19. Gangguan pada hati di-tandai dengan peningkatan serum glutamic oxaloacetic transaminase (SGOT) dan serum glutamic pyruvate transaminase (SGPT). Penelitian yang dilakukan oleh Salbiah et $\mathrm{al}^{12}$ pada 90 pasien COVID-19 di laboratorium Rumah Sakit Umum Adhyaksa Jakarta menunjukkan $76,7 \%$ pasien mengalami kenaikan SGOT dan $77,8 \%$ pasien mengalami kenaikan SGPT. Hal ini terjadi pada sebagian besar pasien dengan gejala sedang. Steatosis mikrovesikular yang terlihat pada biopsi jaringan hati pasien COVID-19 menunjukkan kerusakan pada hati dapat disebabkan oleh infeksi SARS-CoV-2 atau obatobatan. ${ }^{13}$ Omnari-Nava et $\mathrm{al}^{14}$ melaporkan bahwa peningkatan SGOT berhubungan dengan kebutuhan perawatan intensif dan mortalitas. Hal ini sejalan dengan penelitian Huang et $\mathrm{al}^{15}$ pada 41 pasien COVID-19 yang menunjukkan SGOT dan SGPT meningkat bermakna pada pasien ICU dibandingkan pasien non-ICU. Cai et a ${ }^{16}$ melaporkan, dari 417 pasien COVID-19, 318 (76,3\%) memiliki hasil tes fungsi hati yang abnormal dan $90(21,5 \%)$ pasien mengalami gangguan fungsi hati ketika dirawat di rumah sakit. Dari 318 pasien, 26,7\% mengalami pneumonia berat. Peningkatan SGPT dan gammaglutamyltransferase (GGT) banyak terjadi (masing-masing pada 37\% dan $41 \%$ pasien), sedangkan peningkatan SGOT dan total bilirubin (TBIL) lebih sedikit terjadi (masing-masing pada $20 \%$ dan $10 \%$ pasien). Karena itu, menurut Cai et al, ${ }^{16}$ tes fungsi 
hati yang abnormal dapat menjadi prediktor terhadap tingkat keparahan penyakit pada COVID-19.

Perubahan fisiologik yang terjadi selama kehamilan, termasuk penurunan sistem imun menyebabkan wanita hamil lebih mudah terinfeksi SARS-CoV-2. ${ }^{17}$ Ushida et $\mathrm{al}^{18}$ melaporkan bahwa nilai SGPT sedikit menurun pada trimester ketiga karena terjadi peningkatan volume plasma (hemodilusi), sedangkan nilai SGOT tidak berubah. Studi yang dilakukan oleh Deng et al ${ }^{19}$ pada 37 wanita hamil terkonfirmasi COVID-19 di Wuhan melaporkan bahwa prevalensi kerusakan hati pada wanita hamil terkonfirmasi COVID-19 sebesar 29,7\%. Wanita hamil terkonfirmasi COVID-19 dengan kerusakan hati mengalami inflamasi yang lebih berat daripada wanita hamil dengan fungsi hati normal

Becermin pada latar belakang yang telah dipaparkan maka penulis tertarik untuk mengetahui gambaran SGOT dan SGPT pada wanita hamil terkonfirmasi COVID-19 yang dirawat di RSUP Prof. Dr. R. D. Kandou periode Juli-Agustus 2021.

\section{METODE PENELITIAN}

Penelitian ini dilakukan di Instalasi Rekam Medik dan laboratorium RSUP Prof. Dr. R. D. Kandou Manado pada bulan Oktober-Desember 2021 dengan menggunakan data sekunder berupa catatan rekam medik pasien. Jenis penelitian ini ialah deskriptif retrospektif. Untuk menentukan sampel penelitian digunakan kriteria inklusi yaitu wanita hamil terkonfirmasi COVID-19 yang dirawat di RSUP Prof. Dr. R. D. Kandou Manado dan datanya tercatat dalam rekam medik bulan Juli-Agustus 2021. Pasien dikatakan terkonfirmasi COVID-19, jika mendapatkan hasil positif pada pemeriksaan RT-PCR. Kriteria eksklusi ialah pasien yang data rekam mediknya tidak lengkap. Nilai referensi nilai SGOT dan SGPT yang dipakai merupakan rentang nilai untuk wanita hamil sesuai usia kehamilan (trimester) berdasarkan penelitian oleh Dai et al $(2018)^{20}$. Peningkatan SGOT dan SGPT dikatakan bermakna klinis, jika meningkat dua kali dari nilai normal. ${ }^{21}$

\section{HASIL PENELITIAN}

Penelitian ini menggunakan data rekam medik wanita hamil terkonfirmasi COVID19 di RSUP Prof. Dr. R. D. Kandou Manado pada periode Juli-Agustus 2021. Terdapat 51 pasien yang memenuhi kriteria inklusi dengan 40 pasien yang dirawat pada bulan Juli 2021 dan 11 pasien dirawat pada bulan Agustus 2021.

Tabel 1 memperlihatkan bahwa wanita hamil terkonfirmasi COVID-19 yang dirawat di RSUP Prof. Dr. R. D. Kandou pada bulan Juli-Agustus 2021 menurut kelompok usia. Kelompok usia terbanyak ialah 26-30 tahun (25\%), diikuti kelompok usia 31-35 tahun $(23 \%)$. Kelompok usia yang paling sedikit ialah 11-15 tahun dan 45-50 tahun (masing-masing 2\%).

Tabel 1. Distribusi usia pada kehamilan dengan COVID-19

\begin{tabular}{ccc}
\hline $\begin{array}{c}\text { Kelompok } \\
\text { usia } \\
\text { (tahun) }\end{array}$ & Frekuensi & $\begin{array}{c}\text { Persentase } \\
(\%)\end{array}$ \\
\hline $11-15$ & 1 & 2 \\
$16-20$ & 5 & 10 \\
$21-25$ & 8 & 16 \\
$26-30$ & 13 & 25 \\
$31-35$ & 12 & 23 \\
$36-40$ & 9 & 18 \\
$41-45$ & 2 & 4 \\
$45-50$ & 1 & 2 \\
Total & 51 & 100 \\
\hline
\end{tabular}

Wanita hamil pada penelitian ini terutama berada pada trimester III yaitu 49 orang $(96 \%)$ sedangkan pada trimester II sebanyak dua orang (4\%). Tidak terdapat wanita hamil trimester I.

Tabel 2 memperlihatkan bahwa menurut kategori gejala, yang terbanyak ialah wanita hamil dengan gejala sedang sebanyak 18 pasien (35\%), namun terdapat juga yang asimtomatik atau tanpa gejala sebanyak dua pasien (4\%). Sebanyak 14 wanita hamil $(27 \%)$ tidak memiliki data gejala.

Tabel 3 memperlihatkan bahwa pada wanita hamil trimester II terdapat satu pasien tanpa gejala $(50 \%)$ dan satu pasien 
dengan gejala sedang (50\%). Pada wanita hamil trimester III didapatkan terbanyak ialah yang dengan gejala sedang 17 pasien (35\%) diikuti yang dengan gejala ringan sebanyak 10 pasien $(20 \%)$ namun masih terdapat 1 pasien $(2 \%)$ yang asimtomatik. Tidak terdapat wanita hamil trimester I.

Tabel 2. Gambaran jumlah pasien berdasarkan gejala

\begin{tabular}{lcc}
\hline \multicolumn{1}{c}{ Gejala } & Frekuensi & $\begin{array}{c}\text { Persentase } \\
(\mathbf{\%})\end{array}$ \\
\hline Asimptomatik & 2 & 4 \\
Ringan & 10 & 20 \\
Sedang & 18 & 35 \\
Berat & 7 & 14 \\
Tidak ada data & 14 & 27 \\
gejala & & 100 \\
Total & 51 & \\
\hline
\end{tabular}

Tabel 4 memperlihatkan bahwa pada wanita hamil trimester II terdapat satu pasien dengan nilai SGOT <27 U/L (50\%) dan satu pasien dengan nilai SGOT pada rentang 27-54 U/L (50\%). Pada wanita hamil trimester III, terbanyak ialah yang memiliki nilai SGOT <27 U/L (51\%), diikuti yang dengan nilai SGOT pada rentang 26-52 U/L (31\%), dan yang dengan nilai $\mathrm{SGOT}>52 \mathrm{U} / \mathrm{L}(18 \%)$.

Tabel 5 memperlihatkan bahwa pada wanita hamil trimester II terdapat dua pasien (100\%) yang memiliki nilai SGPT <35 U/L. Pada wanita hamil trimester III terbanyak ialah yang memiliki nilai SGPT <35 U/L (84\%) sedangkan yang memiliki nilai SGPT pada rentang 35-70 U/L dan nilai SGPT $>70$ U/L berjumlah sama (masing-masing $8 \%$ ).

Tabel 3. Gambaran gejala pada pasien trimester I, II, dan III

\begin{tabular}{lccc}
\hline \multicolumn{1}{c}{ Gejala } & $\begin{array}{c}\text { Trimester I } \\
\text { Frekuensi } \\
\text { (Persentase) }\end{array}$ & $\begin{array}{c}\text { Trimester II } \\
\text { Frekuensi } \\
\text { (Persentase) }\end{array}$ & $\begin{array}{c}\text { Trimester III } \\
\text { Frekuensi } \\
\text { (Persentase) }\end{array}$ \\
\hline Asimtomatik & 0 & $1(50)$ & $1(2)$ \\
Ringan & 0 & $0(0)$ & $10(20)$ \\
Sedang & 0 & $1(50)$ & $17(35)$ \\
Berat & 0 & $0(0)$ & $7(14)$ \\
Tidak ada data gejala & 0 & $0(0)$ & $14(29)$ \\
Total & 0 & $2(100)$ & $49(100)$ \\
\hline
\end{tabular}

Tabel 4. Gambaran rentang nilai SGOT pada pasien trimester II dan III

\begin{tabular}{ccc}
\hline $\begin{array}{c}\text { Rentang Nilai } \\
\text { SGOT (U/L) }\end{array}$ & $\begin{array}{c}\text { Trimester II } \\
\text { Frekuensi } \\
\text { (Persentase) }\end{array}$ & $\begin{array}{c}\text { Trimester III } \\
\text { Frekuensi } \\
\text { (Persentase) }\end{array}$ \\
\hline$<27$ & $1(50)$ & $25(51)$ \\
$27-54$ & $1(50)$ & $15(31)$ \\
$>54$ & $0(0)$ & $9(18)$ \\
Total & 2 & 49 \\
\hline
\end{tabular}

Tabel 5. Gambaran rentang nilai SGPT pada pasien trimester II dan III

\begin{tabular}{ccc}
\hline $\begin{array}{c}\text { Rentang Nilai } \\
\text { SGPT (U/L) }\end{array}$ & $\begin{array}{c}\text { Trimester II } \\
\text { Frekuensi } \\
\text { (Persentase) }\end{array}$ & $\begin{array}{c}\text { Trimester III } \\
\text { Frekuensi } \\
\text { (Persentase) }\end{array}$ \\
\hline$<35$ & $2(100)$ & $41(84 \%)$ \\
$35-70$ & $0(0)$ & $4(8 \%)$ \\
$>70$ & $0(0)$ & $4(8 \%)$ \\
Total & 2 & 100 \\
\hline
\end{tabular}




\section{BAHASAN}

Pada penelitian ini, dikumpulkan data rekam medik pasien wanita hamil terkonfirmasi COVID-19 yang dirawat di RSUP Prof. Dr. R. D. Kandou pada bulan Juli Agustus 2021 dan didapatkan 51 pasien yang memenuhi kriteria inklusi. Pada distribusi pasien berdasarkan kelompok usia, jumlah pasien terbanyak ialah pada kelompok usia 26-30 tahun (25\%), diikuti kelompok usia 31-35 tahun (23\%), sedangkan jumlah pasien paling sedikit berada pada kelompok usia 11-15 tahun dan 45-50 tahun (masing-masing 2\%). Kelompok usia 26-30 tahun dan 31-35 tahun yang memiliki jumlah pasien terbanyak berkaitan dengan usia reproduksi sehat wanita, yaitu 20-35 tahun. ${ }^{23}$

Pada distribusi pasien berdasarkan usia kehamilan, didapatkan pasien terbanyak ialah pasien trimester III, yaitu 49 pasien (96\%), diikuti pasien trimester II berjumlah 2 pasien (4\%); tidak didapatkan pasien trimester I $(0 \%)$. Hal ini sejalan dengan penelitian yang dilakukan oleh Chen et $\mathrm{al}^{4}$ yang melaporkan bahwa dari 118 kasus kehamilan dengan COVID-19, terdapat 75 (64\%) pasien trimester III. Penelitian lain oleh Sahin et $\mathrm{al}^{24}$ melaporkan wanita hamil trimester III memiliki tingkat rawat inap di rumah sakit tertinggi dibandingkan trimester I dan II; hal ini mungkin disebabkan karena kekhawatiran dokter. ${ }^{24}$ Pada trimester III, perubahan fisiologik yang terjadi lebih banyak dan dapat menimbulkan rasa kurang nyaman, misalnya konstipasi, sakit punggung, sakit perut yang ringan, sesak napas akibat pembesaran uterus hingga menekan diafragma, dan kondisi hiperkoagulasi yang mencapai puncak pada trimester III sehingga wanita hamil trimester III lebih berisiko untuk dirawat di rumah sakit. ${ }^{25-27}$

Pada penelitian ini, terdapat 47 pasien yang memiliki data gejala, sedangkan 14 pasien tidak memiliki data gejala (27\%). Frekuensi terbanyak ialah pasien dengan gejala sedang (35\%), diikuti pasien dengan gejala ringan $(20 \%)$, pasien dengan gejala berat $(14 \%)$, dan frekuensi paling sedikit ialah pasien tanpa gejala atau asimtomatik (4\%). Pada distribusi gejala berdasarkan usia kehamilan, terdapat 1 pasien trimester II dengan gejala sedang (50\%) dan 1 pasien tanpa gejala (50\%). Pada pasien trimester III, didapatkan frekuensi terbanyak ialah pasien dengan gejala sedang (35\%), diikuti pasien dengan gejala ringan $(20 \%)$, pasien dengan gejala berat (14\%), dan frekuensi paling sedikit ialah pasien tanpa jumlah 1 pasien (2\%). Systematic review yang dilakukan oleh Yang et $\mathrm{al}^{28}$ melaporkan bahwa 96,5\% wanita hamil dengan COVID-19 memiliki gejala ringan, $5,3 \%$ pasien mengalami gejala berat, dan dua pasien yang asimtomatik. Perkumpulan Obstetri dan Ginekologi Indonesia (POGI) melaporkan pada bulan April 2020 hingga April 2021 terdapat $51,9 \%$ wanita hamil asimtomatik, $4,5 \%$ masuk ICU, dan $3 \%$ meninggal. ${ }^{8}$ Umumnya studi melaporkan bahwa sebagian besar kasus kehamilan dengan COVID19 ialah gejala ringan dan sedang, namun pada kasus berat dapat menyebabkan ibu hamil masuk ruang ICU, bahkan kematian. ${ }^{29}$

Reseptor ACE2 yang terdapat pada sistem perncernaan, termasuk pada hepatosit dan kolangiosit menyebabkan munculnya manifestasi klinis berupa gejala digestif (diare, mual, dan muntah) dan gangguan fungsi hati pada pasien COVID-19. ${ }^{30}$ Gangguan fungsi hati dapat ditandai dengan peningkatan SGOT dan SGPT. Gangguan fungsi hati pada COVID-19 dapat terjadi sebagai akibat langsung dari infeksi SARSCoV-2 pada hepatosit dan kolangiosit, efek obat tertentu, inflamasi sistemik, iskemia dan hipoksia hati, dan penyakit hati bawaan. ${ }^{30}$ Pada kehamilan normal tanpa infeksi SARS-CoV-2, nilai SGPT sedikit menurun pada trimester III sedangkan nilai SGOT tidak berubah selama kehamilan. ${ }^{18}$ SGPT merupakan marker spesifik terhadap kerusakan hati karena banyak terdapat di hati dan lebih sedikit ditemui di jantung dan otot skelet dibandingkan SGOT. ${ }^{31}$

Berdasarkan distribusi nilai SGOT pada pasien trimester II, didapatkan satu pasien (50\%) mengalami sedikit peningkatan SGOT, yaitu pada rentang 27-54 U/L dan 1 pasien $(50 \%)$ memiliki nilai SGOT normal, yaitu <27 U/L. Pada pasien trimester III, terdapat 15 pasien $(31 \%)$ yang mengalami 
sedikit peningkatan SGOT pada rentang 26$52 \mathrm{U} / \mathrm{L}, 9$ pasien (18\%) memiliki nilai SGOT yang sangat meningkat, yaitu $>52 \mathrm{U} / \mathrm{L}$, dan 25 pasien $(51 \%)$ memiliki nilai SGOT normal, yaitu $<26 \mathrm{U} / \mathrm{L}$. Pada distribusi nilai SGPT pasien trimester II, kedua pasien (100\%) memiliki nilai SGPT normal, yaitu $<35 \mathrm{U} / \mathrm{L}$, sedangkan pada pasien trimester III, terdapat empat pasien $(8 \%)$ yang mengalami sedikit peningkatan SGPT pada rentang 29-58 U/L, empat pasien (8\%) memiliki nilai SGPT yang sangat meningkat, yaitu $>58 \mathrm{U} / \mathrm{L}$, dan 41 pasien $(84 \%)$ memiliki nilai SGPT normal, yaitu <29 U/L. Data ini memperlihatkan bahwa lebih banyak pasien yang mengalami peningkatan SGOT (satu pasien trimester II dan 24 pasien trimester III) daripada SGPT (delapan pasien trimester III). Hal ini dapat dikaitkan dengan nilai SGOT pada hepatosit yang tiga sampai empat kali lebih banyak daripada SGPT. SGOT juga terdapat pada banyak organ, seperti miokardium, otot skelet, dan eritrosit sehingga peningkatannya bisa lebih tinggi daripada SGPT. ${ }^{32}$ Hal ini sejalan dengan penelitian oleh Sun et $\mathrm{al}^{33}$ yang melaporkan bahwa nilai SGOT dan SGPT (rerata 22,33 dan 15,07 U/L) lebih tinggi pada wanita hamil terkonfirmasi COVID-19 daripada nilai SGOT dan SGPT (rerata 16,59 dan 10,03 U/L) pada wanita hamil yang tidak terinfeksi SARS-CoV-2. Peningkatan SGOT pada kedua kelompok juga lebih tinggi daripada peningkatan SGPT

Penelitian lain yang sejalan dengan hasil penelitian ini ialah studi cohort retrospektif yang dilakukan oleh Can et al. ${ }^{34}$ Dari 122 wanita hamil terkonfirmasi COVID-19, 17 (13,9\%) pasien mengalami peningkatan nilai parameter tes fungsi hati. Ditemukan peningkatan nilai SGOT dan SGPT ringan, yaitu $<5$ kali dari nilai normal. Tes fungsi hati yang abnormal berhubungan dengan waktu perawatan di rumah sakit yang lebih lama. Pemberian lopinavir/ ritonavir dan hydrochloroquine lebih tinggi dan lebih lama pada pasien dengan hasil tes fungsi hati yang abnormal daripada pasien dengan hasil tes fungsi hati yang normal. Hal ini menunjukkan bahwa obat-obatan juga dapat menjadi risiko terjadinya gang- guan fungsi hati selama pasien dirawat di rumah sakit. ${ }^{34}$

Studi multicenter yang dilakukan oleh Qi et al ${ }^{35}$ pada 70 pasien terinfeksi SARSCoV-2 tanpa penyakit hati bawaan, melaporkan bahwa 32 dari 70 pasien mengalami gangguan fungsi hati pada saat masuk rumah sakit. 15 pasien mengalami peningkatan SGPT, lima pasien mengalami peningkatan SGOT, dan 25 pasien mengalami peningkatan total bilirubin. Lamanya waktu masuk rumah sakit sejak terinfeksi menyebabkan risiko yang lebih tinggi untuk terjadi gangguan fungsi hati pada pasien COVID-19. Antivirus yang dipakai selama perawatan, termasuk lopinavir dan ritonavir dapat memperberat gangguan fungsi hati yang terjadi pada pasien. ${ }^{35}$

Penelitian lain yang dilakukan oleh Mishra et al $^{36}$ melaporkan bahwa peningkatan nilai SGOT dan SGPT berhubungan dengan peningkatan risiko mortalitas. Peningkatan transaminase dapat menjadi prediktor dari acute hypoxic respiratory failure yang menyebabkan pasien membutuhkan ventilasi mekanik. Pasien dengan peningkatan transaminase ringan juga berisiko tinggi untuk mengalami infeksi sekunder dan harus diidentifikasi untuk diberikan antibiotik lebih awal. Mishra et $\mathrm{al}^{36}$ juga melaporkan adanya korelasi positif antara gangguan fungsi hati dengan peningkatan D-dimer, ferritin, lactate dehydrogenase (LDH), dan creatine phosphokinase (CPK). Gangguan fungsi hati juga berhubungan dengan inflammatory syndrome yang disebabkan oleh COVID-19. ${ }^{36}$

Penelitian ini tidak membandingkan nilai SGOT dan SGPT pada wanita hamil terkonfirmasi COVID-19 yang memiliki komorbid dengan wanita hamil terkonfirmasi COVID-19 tanpa komorbid. Penelitian Sun et $\mathrm{al}^{33}$ melaporkan perbedaan nilai SGOT dan SGPT pada wanita hamil terkonfirmasi COVID-19 yang mempunyai komorbid (diabetes dan hipertensi), wanita hamil terkonfirmasi COVID-19 tanpa komorbid, dan wanita hamil yang tidak terinfeksi SARS-CoV-2. Wanita hamil terkonfirmasi COVID-19 dengan hipertensi memiliki nilai SGOT dan SGPT yang lebih tinggi daripada 
wanita hamil terkonfrimasi COVID-19 tanpa hipertensi dan wanita hamil yang tidak terinfeksi SARS-CoV-2. Nilai SGOT dan SGPT pada wanita hamil terkonfirmasi COVID-19 dengan diabetes juga sedikit lebih tinggi daripada nilai SGOT dan SGPT pada wanita hamil terkonfirmasi COVID-19 tanpa diabetes dan wanita hamil yang tidak terinfeksi SARS-CoV-2. Hal ini menunjukkan bahwa penyakit kronis dapat memediasi kerusakan hati pada pasien COVID-19. Karena itu, pengobatan COVID-19 harus berfokus pada mengatasi inflamasi dan kerusakan hati, terutama pada pasien dengan penyakit kronis. ${ }^{33}$

\section{SIMPULAN}

Pada wanita hamil terkonfirmasi COVID-19 yang dirawat di RSUP Prof. Dr. R. D. Kandou periode Juli -Agustus 2021, didapatkan lebih banyak pasien yang memiliki nilai SGOT normal dan SGPT normal. Wanita hamil yang mengalami peningkatan nilai SGOT lebih banyak daripada yang mengalami peningkatan nilai SGPT.

\section{Konflik Kepentingan}

Penulis menyatakan tidak terdapat konflik kepentingan dalam studi ini.

\section{DAFTAR PUSTAKA}

1. Susilo A, Rumende MC, Pitoyo CW, Santoso DW, Yulianti M, Sinto R, et al. Coronavirus disease 2019: tinjauan literatur terkini. Jurnal Penyakit Dalam Indonesia [Internet]. 2020;7(1). Available from: https://www.ncbi.nlm.nih. gov/nuccore/

2. Elsadig AE, Ali MM, Yousif AA. Laboratory manifestations of COVID-19 associated with hemostatic abnormalities. Journal of Ideas in Health. 2021;4(3):423-7.

3. Kementerian Kesehatan Republik Indonesia. Situasi terkini perkembangan coronavirus disease (COVID-19) [Internet]. 2021. Available from: https: //infeksiemerging.kemkes.go.id

4. Chen L, Li Q, Jiang H, Wei Y, Zuo L, Feng L, et al. Clinical characteristics of pregnant women with covid-19 in Wuhan. The New England Journal of Medicine. 2020;382(25):e100.
5. Wu YT, Li C, Zhang CJ, Huanf HF. Is termination of early pregnancy indicated in women with COVID-19. Correspondence/ Eur J Obstet Gynecol Reprod Biol. 2020; 251:266-84. Doi: 10.1016/j. ejogrb.2020.05.037.

6. Kadiwar S, Smith JJ, Ledot S, Johnson M, Bianchi P, Singh N, et al. Were pregnant women more affected by COVID-19 in the second wave of the pandemic? Lancet. 2021;397(10284):1539-40.

7. Iftimie S, López-Azcona AF, Vallverdú I, Hernàndez-Flix S, de Febrer G, Parra S, et al. First and second waves of coronavirus disease-19: A comparative study in hospitalized patients in Reus, Spain. Available from:https://doi.org/ 10.1101/ 2020.12.10.20246959

8. Perkumpulan Obstetri dan Ginekologi Indonesia (POGI). Rekomendasi POGI terkait dengan melonjaknya kasus ibu hamil dengan Covid-19 dan perlindungan terhadap tenaga kesehatan. 2021 [cited 2021 Oct 18]; Available from: https://pogi.or.id/publish/wp-content/ uploads/2021/06/Revisi-RekomendasiPOGI-utk-Bumil-dengan-Covid-19.pdf

9. Polónia-Valente R, Moucho M, Tavares M, Vilan A, Montenegro N, Rodrigues T. Vaginal delivery in a woman infected with SARS-CoV-2 - The first case reported in Portugal. Eur J Obstet Gyneco; Reprod Biol. 2020;250:253-4. Doi: 10.1016/j.ejogrb.2020.05.007.

10. Wang D, Hu B, Hu C, Zhu F, Liu X, Zhang J, et al. Clinical characteristics of 138 hospitalized patients with 2019 novel coronavirus-infected pneumonia in Wuhan, China. JAMA. 2020;323(11): 1061-9.

11. Agarwal A, Chen A, Ravindran N, To C, Thuluvath PJ. Gastrointestinal and liver manifestations of COVID-19. J Clin Exp Hepatol. 2020;10(3):263-5. Doi: 10.1016/j.jceh.2020.03.001

12. Salbiah, Liza, Dina I, Sri A. Relationship characteristics of COVID-19 patients with SGOT and SGPT levels. Syedza Saintika. 2021;1(1):88-97.

13. Xu Z, Shi L, Wang Y, Zhang J, Huang L, Zhang C, et al. Pathological findings of COVID-19 associated with acute respiratory distress syndrome. Lancet Respir Med. 2020;8(4):420-2. 
14. Omrani-Nava V, Maleki I, Ahmadi A, Moosazadeh M, Hedayatizadeh-Omran A, Roozbeh F, et al. Evaluation of hepatic enzymes changes and association with prognosis in COVID-19 patients. Hepatitis Monthly. 2020;20(4) :e103179. Doi:10.5812/hepatmon.103 179.

15. Huang C, Wang Y, Li X, Ren L, Zhao J, Hu Y, et al. Clinical features of patients infected with 2019 novel coronavirus in Wuhan, China. Lancet. 2020;395 (10223):497-506.

16. Cai Q, Huang D, Yu H, Zhu Z, Xia Z, Su Y, et al. COVID-19: Abnormal liver function tests. J Hepatol. 2020;73(3):566-74.

17. Chen H, Guo J, Wang C, Luo F, Yu X, Zhang $\mathrm{W}$, et al. Clinical characteristics and intrauterine vertical transmission potential of COVID-19 infection in nine pregnant women: a retrospective review of medical records. Lancet. 2020;395 (10226):809-15.

18. Ushida T, Kotani T, Kinoshita F, Imai K, Nakano-Kobayashi T, Nakamura N, et al. Liver transaminase levels during pregnancy: a Japanese multicenter study. J Matern-Fetal Neonatal Med. 2021. Available from: https://doi.org/ 10.1080/14767058.2021.1892633

19. Deng G, Zeng F, Zhang L, Chen H, Chen X, Yin M. Characteristics of pregnant patients with COVID-19 and liver injury. J Hepatol. 2020;73(4):989-91.

20. Dai Y, Liu J, Yuan E, Li Y, Wang Q, Jia L, et al. Gestational age-specific reference intervals for 15 biochemical measurands during normal pregnancy in China. Ann Clin Biochem. 2018;55(4):446-52.

21. Aminah S. Perbedaan kadar SGOT, SGPT, ureum, dan kreatinin pada penderita TB paru setelah enam bulan pengobatan. Jurnal Analis Kesehatan. 2013;2(2): 260-9.

22. Kementerian Kesehatan Republik Indonesia. Keputusan Menteri Kesehatan Republik Indonesia Nomor HK.01.07/MENKES/ 4641/2021 Tentang Panduan Pelaksanaan Pemeriksaan, Pelacakan, Karantina, Dan Isolasi Dalam Rangka Percepatan Pencegahan Dan Pengendalian Coronavirus Disease 2019 (COVID-19)

23. Lubis N. Psikologi Kespro. Wanita dan Perkembangan Reproduksinya: Ditinjau dari Aspek Fisik dan Psikologinya.
Jakarta: Kencana; 2013.

24. Sahin D, Tanacan A, Erol SA, Yetiskin YFD, Besimoglu B, Ozden Tokalioglu E, et al. Management of pregnant women with COVID-19: a tertiary pandemic center experience on 1416 cases. J Med Virol 2021;1-11. Doi:10.1002/jmv.27423

25. Dharma R, Panjaitan MT, Sumapradja K, Setiabudy R. Profile of D-dimer in uncomplicated pregnancy. Profil Ddimer Kehamilan tanpa Komplikasi. Indones J Obstet Gynecol (INAJOG). 2019;7(4):283-8.

26. Askari M. Pengetahuan ibu hamil tentang perubahan fisiologis pada kehamilan di Poli Kandungan RSU Dewi Sartika Kota Kendari tahun 2017 [Karya tulis ilmiah]. Kendari; Politeknik Kesehatan Kendari; 2017.

27. Kusuma R. Studi kualitatif: pengalaman adaptasi ibu hamil. Jurnal Akademika Baiturrahim Jambi. 2018;7(2):148-64.

28. Yang Z, Wang M, Zhu Z, Liu Y. Coronavirus disease 2019 (COVID-19) and pregnancy: a systematic review. J Matern-Fetal Neonatal Med. 2020. Available from: https://doi.org/10.1080/14767058.2020. 1759541

29. Rohmah MK, Nurdianto AR. Corona virus disease 2019 (COVID-19) pada wanita hamil dan bayi: sebuah tinjauan literatur. Med Hosp. 2020;7(1A)7:329-36.

30. Li J, Fan JG. Characteristics and mechanism of liver injury in 2019 coronavirus disease. J Clin Transl Hepatol. 2020;8(1)8:13-7. Doi: 10.14218/JCTH.2020.00019

31. Kendran AAS, Arjana AAG, Pradnyantari AASI. Aktivitas enzim alanine-aminotransferase dan aspartat aminotransferase pada tikus putih jantan yang diberi ekstrak buah pinang. Buletin Veteriner Udayana. 2017;9(2):132-8.

32. Pane R. Pemeriksaan SGOT dan SGPT pada pasien di Balai Laboratorium Kesehatan Daerah Provinsi Sumatera Utara [Tugas Akhir]. Medan: Universitas Sumatera Utara; 2016.

33. Sun G, Zhang Y, Liao Q, Cheng Y. Blood test results of pregnant COVID-19 patients: an updated case-control study. Front Cell Infect Microbiol. 2020; 10:560899. Doi: 10.3389/fcimb.2020.560899

34. Can E, Oğlak S, Ölmez F. Abnormal liver function tests in pregnant patients with COVID-19-a retrospective cohort study 
142 Medical Scope Journal (MSJ), Volume 3, Nomor 2, Januari-Juni 2022, hlm. 134-142

in a tertiary center. Ginekologia Polska [Internet]. 2021:1-6. Available from: https://journals.viamedica.pl/ginekolo gia_polska/article/view/GP.a2021.01 82/64478

35. Qi X, Liu C, Jiang Z, Gu Y, Guo Z, Chuxiao $S$, et al. Multicenter analysis of clinical characteristics and outcomes in patients with COVID-19 who develop liver injury. J Hepatol. 2020;73(2):455-8.

36. Mishra K, Naffouj S, Gorgis S, Ibrahim H, Gill $\mathrm{S}$, Fadel $\mathrm{R}$, et al. Liver injury as a surrogate for inflammation and predicttor of outcomes in COVID-19. Hepatol Commun. 2021;5(1):24-32. 